\title{
A tribute to Narr (1952): On the stratigraphy of Upper Palaeolithic types and type groups
}

\author{
Nicholas J. Conard ${ }^{1,2}$ \\ ${ }^{1}$ Department of Early Prehistory and Quaternary Ecology, University of Tübingen, Schloss Hohentübingen, \\ 72070 Tübingen, Germany \\ ${ }^{2}$ Senckenberg Centre for Human Evolution and Paleoenvironment, University of Tübingen, 72070 Tübingen, Germany
}

Correspondence: Nicholas J. Conard (nicholas.conard@uni-tuebingen.de)

Relevant dates: $\quad$ Received: 13 October 2021 - Accepted: 30 October 2021 - Published: 17 December 2021

How to cite: Conard, N. J.: A tribute to Narr (1952): On the stratigraphy of Upper Palaeolithic types and type groups, E\&G Quaternary Sci. J., 70, 213-216, https://doi.org/10.5194/egqsj-70-213-2021, 2021.

Special issue statement. This article is part of a special issue published on the occasion of the 70th anniversary of $E \& G$ Quaternary Science Journal (EGQSJ). The special issue celebrates the journal's notable contribution to Quaternary research by revisiting selected milestone articles published in the long history of EGQSJ. The German Quaternary Association (DEUQUA) presents translations of the originals and critical appraisals of their impact in tandem anniversary issues of DEUQUASP and EGQSJ, respectively.

Original article: https://doi.org/10.3285/eg.02.1.06

Translation: https://doi.org/10.5194/deuquasp-327-2021

\section{Main text}

Karl J. Narr's (1921-2009) paper in the inaugural volume of EAG presents a critical review of the taxonomy and organization of the European Upper Palaeolithic. At the same time, the contribution addresses the European cultural stratigraphic record within a theoretical framework grounded within the cultural historical approach. The paper touches upon questions related to cultural change and the appearance and spread of innovative technologies. Interestingly, the paper almost never mentions Upper Palaeolithic hunter-gatherers. At times the author gives the impression that it is the artefacts themselves that shaped Palaeolithic prehistory rather than past peoples. Narr drew heavily on key sites, many of which are still important today, and addressed research questions that are discussed as much now as in Narr's day prior to the advent of radiocarbon dating, climatic records based on deep sea cores or ice cores, aDNA, and many other sources of data that are central to research today.

If we consider the terminology that Narr used, the main cultural groups including the Chatelperronian, the Aurignacian, the Gravettian, the Solutrean and the Magdalenian are all terms used today. Narr, however, discussed numerous other cultural groups that today have fallen out of use and that few current researchers would recognize. The paper also addresses the strengths and weaknesses of Denis Peyrony's (1933) concept of the Perigordian tradition extending over most of the Upper Palaeolithic, and it ultimately favours Dorothy Garrod's (1938) concept of the Gravettian cultural group as a revision to both Breuil's (1912) concept of a long Aurignacian cultural tradition and Peyrony's system. In many respects, Narr's assessment is consistent with the general terminology of today, and Palaeolithic archaeologists still debate the origins and spread of cultural markers of the Upper Palaeolithic.

Given the lack of absolute dates for the Upper Palaeolithic sequence, it comes as no surprise that Narr constructed a stratigraphic system without explicit dates for the four stages he defines. These stages are further subdivided into substages. In this system, Narr, for example, argued that 
Chatelperronian points and other Chatelperronian forms date no earlier than to Stage 1 in Western Europe, while at the same time we have the earliest appearance of Aurignacian points and carinated scrapers in Central Europe. These sorts of claims are consistent with recent work which suggests a temporal overlap between the Central European Aurignacian and the Western European Chatelperronian (Higham et al., 2012). In contemporary terms, we would see this period as corresponding to the millennia preceding the Heinrich 4 event and dating in the vicinity of 42-43 ka cal BP using the radiocarbon chronology (Fig. 1). Narr's figure on page 60 suggests that the Chatelperronian spread from Western Europe into Central Europe, bringing with it early Gravettian elements, which today is not a plausible point of view. Also, if we ask what Stage 1 meant to Narr, it becomes clear that his Stage 1, reflecting a warm period, mainly loamy cave deposits and the Göttweiger soil development of the loess stratigraphy, is completely out of date and irrelevant for current research. Furthermore, considerable research in recent years has shown that the cultural variability at the beginning of the Upper Palaeolithic reflects a fluid continuity within adaptive technological systems rather than unvarying typological patterns that are easily attributed to specific cultural groups (Bataille et al., 2018).

Moving up the stratigraphic sequence, Narr viewed the horizon of the Gravettian with Noailles burins as dating to no earlier than his Stage $3 b$ in Western and Central Europe, while he argues that in Western Europe this time corresponds to the first appearance of triangularly retouched pieces. Stage $3 \mathrm{~b}$ corresponds to the cold continental conditions at the end of Würm II. In caves, this period corresponds to a phase of deposition of coarse angular limestone debris and in the open air to the end of a phase of pure loess deposition within his Loess III. In a broad sense, this assessment is consistent with the placement of the Gravettian within a general phase of cold continental conditions in Europe leading up to the Last Glacial Maximum, but the details of the stratigraphic assessment are of little relevance today, as many new methods allow for an improved cultural chronology and palaeoenvironmental assessment.

A final example is the initial presence of double-rowed Magdalenian harpoons in Stage 4a, which corresponds to conditions in caves and the open air that are similar to those at the time of the appearance of Noailles burins. While one commiserates with the challenges that researchers faced in the middle of the 20th century, it is clear that these sorts of general stratigraphic assessments are not helpful today in establishing a reliable chronostratigraphic framework.

What I find exceptional about Narr's paper is the near absence of statements on specific ecological conditions and his apparent lack of interest in attempting to use faunal assemblages, which at that time were comparatively wellunderstood, for establishing reliable palaeoenvironmental interpretations. The relatively general stratigraphic and lithological correlations that Narr made are, while more or less valid, very broad and do not provide a high level of resolution. What is, however, clear from Narr's paper is that in a period prior to the advent of radiometric dating, diagnostic artefacts could in some cases be used to establish a degree of chronostratigraphic control. This use of cultural stratigraphic markers persists in some contexts today, but in many settings, radiometric dates are now given priority over assumptions about the temporal control provided by the presence or absence of specific artefact forms. In many settings today, archaeologists are expected to demonstrate that similar typological forms are indeed of similar age, while in the middle of the 20th century archaeological finds were often considered the best way to establish a relative chronology. Dating using cultural stratigraphy is still done today, but such arguments are often viewed as rough approximations for establishing temporal units.

Perhaps because of the concise nature of Narr's paper, he did not address taphonomy and site formation processes. While in Narr's day researchers were, of course, aware of stratigraphic complications caused by geological, biological and cultural processes, taphonomic studies and geoarchaeological studies today accompany nearly all publications of Pleistocene cultural materials (McPhail and Goldberg, 2018).

Despite his focus on the appearance and disappearance of artefact forms, Narr does at times make schematic remarks about Palaeolithic peoples. He correctly contrasted the biological reproduction of organisms with the cultural reproduction of artefacts. Although he was rarely explicit about his ideas in this respect, it seems that Narr viewed specific artefact forms as clear markers for the movements of populations of peoples. He touched upon the importance of innovations in material culture and the conservative nature of Palaeolithic material culture, but he made no explicit mention of how technological knowledge was passed down and modified from one generation to the next. He also did not remark on how people make artefacts, how both the people who make tools and the tools themselves experience a degree of selective pressure that, all else being equal, would favour human populations who are well-adapted to their ecological niche, and how changing ecological conditions would likely lead to technological adjustments being made in a group's material culture. It seems as if Narr was more interested in the artefacts than the people who made them. This comes as a surprise since, along with Hansjürgen Müller-Beck in Tübingen, Narr enjoyed the reputation of having considered the ethnographic record as providing insights into the lives of Palaeolithic peoples. In his paper from 1952, ice age huntergatherers remain invisible, and human agency is only found in the dark shadows cast by Palaeolithic artefacts. Today we are lucky to have ever-increasing amounts of hominin skeletal material. These fossil finds have fostered studies of individual life histories and reconstructions of ice age diet and lifeways. While the amount of information in aDNA is still relatively scant in the Palaeolithic, archaeo- and palaeogenetic research allows for analyses of the genetic relationships 

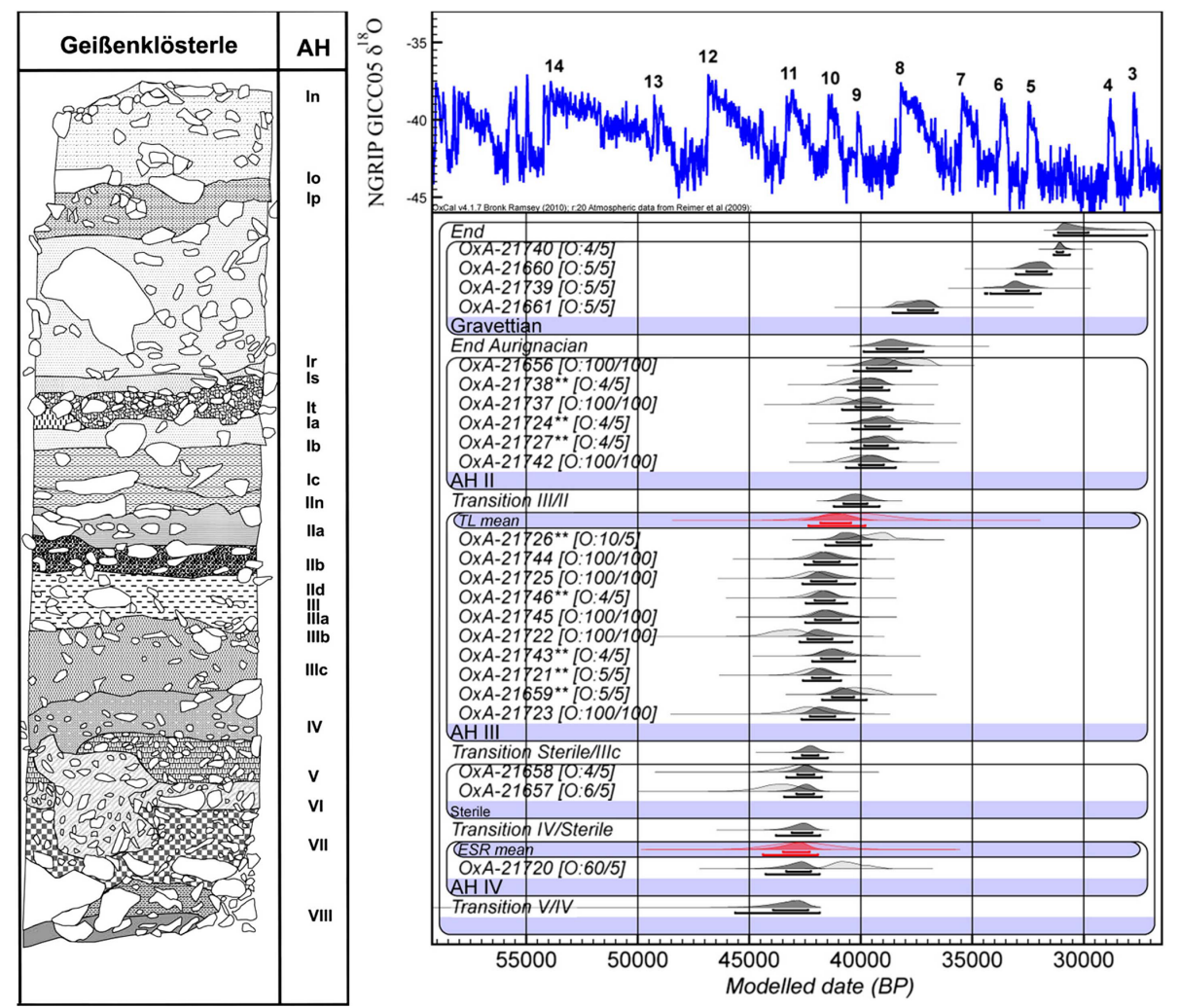

Figure 1. Geißenklösterle. Cultural and chronostratigraphic sequence with calibrated radiocarbon ages and proposed correlations with the NGRIP ice core record from Greenland (based on Higham et al., 2012).

of past individuals and populations in ways that would have been difficult to imagine in a time before the discovery of the structure of DNA and long before the development of routine studies of aDNA that have contributed greatly to our understanding of Palaeolithic population dynamics (Prüfer et al., 2021). Beyond work on aDNA, considerable progress has also been made on diachronic, demographic modelling of Upper Palaeolithic populations (Schmidt et al., 2021), a topic that received little attention at the time of Narr's research.

Turning to Palaeolithic material culture, Narr's paper makes it clear that he, like many of his contemporaries, was highly focused on the use of artefacts as type fossils or fossiles directeurs. He seems to have viewed the typological method uncritically, and he appears to have considered artefact types as explicit signatures of specific prehistoric cultures. Today there is a much stronger tendency to examine the specific technological means by which artefacts are made, as well as their life histories, with an awareness of how raw material availability and constraints dictated by mobility, curation and recycling can shape artefacts and artefact assemblages (Floss, 2012). Similarly, Narr, like his contemporaries, did not consider how functional studies and the study of residues could illuminate our understanding of the design and use of lithic, osseous and botanical artefacts (Plisson and Geneste, 1989). Current microscopic studies document the multifunctionality of tools and their life histories, thereby questioning the concept of tools reflecting singular functional needs of past people or rigid mental templates for tool design. While today's research will likely seem naïve to researchers 70 years from now, Palaeolithic archaeologists today have a more subtle understanding of artefact assemblages based on a wide range of experimental and analytical studies that were not available to Narr.

While Narr's paper was thoughtful and impressive for its day, 70 years later the paper is not read, and as far as I am able to determine it has never been cited in any internationally indexed publication. This underlines the fact that, although the paper contains many important ideas, the improvement of the empirical record of the stratigraphy, chronology and material culture of the Upper Palaeolithic has developed to the point that the paper today mainly has relevance solely in the context of the history of research. This is true of most syntheses of this age and highlights the importance of highquality empirical data that are of lasting value. The lack of interest in the paper could also, in part, reflect the unwillingness of the scientific community in the late 20th and early 21 st century to engage with the German research tradition in Palaeolithic archaeology. Only recently has this tendency begun to change with the international recognition of the importance of contemporary research in Germany, with the in- 
creasing number of international students seeking training in Germany and with ever more international researchers finding research positions in German-speaking Europe (Conard, 2010). Nonetheless, the history of research in Germany is a topic that is almost never addressed outside the Central European research tradition.

Financial support. This open-access publication was funded by the University of Tübingen.

Review statement. This paper was edited by Markus Fuchs and reviewed by Michael Bolus.

\section{References}

Bataille, G., Tafelmaier, Y., and Weniger, G.-C.: Living on the edge - a comparative approach for studying the beginning of the Aurignacian, Quatern. Int., 474, 3-29, https://doi.org/10.1016/j.quaint.2018.03.024, 2018.

Breuil, H.: Les subdivisions du paléolithique supérieur et leur signification, Congrès internat. d'anthrop. et archéol. Préhist., 14, 165-238, 1912.

Conard, N. J.: The Current State of "Paleohistory" in Germany, Mitteilungen der Gesellschaft für Urgeschichte, 19, 193-208, 2010.

Floss, H. (Ed.): Steinartefakte. Vom Altpaläolithikum bis in die Neuzeit, 1. Auflage, Tübingen Publications in Prehistory, Kerns Verlag, Tübingen, Germany, 2012.

Garrod, D. A. E.: The Upper Palaeolithic in the Light of Recent Discovery, P. Prehist. Soc., 4, 1-26, https://doi.org/10.1017/S0079497X00021113, 1938.
Higham, T., Basell, L., Jacobi, R., Wood, R., Ramsey, C. B., and Conard, N. J.: Testing models for the beginnings of the Aurignacian and the advent of figurative art and music: The radiocarbon chronology of Geißenklösterle, J. Hum. Evol., 62, 664-676, https://doi.org/10.1016/j.jhevol.2012.03.003, 2012.

Macphail, R. I. and Goldberg, P.: Applied soils and micromorphology in archaeology, in: Manuals in archaeology, Cambridge University Press, Cambridge, UK, https://doi.org/10.1017/9780511895562, 2018.

Narr, K. J.: Zur Stratigraphie jungpaläolithischer Typen und Typengruppen, E\&G Quaternary Sci. J., 2, 50-62, https://doi.org/10.3285/eg.02.1.06, 1952.

Peyrony, D.: Les Industries " aurignaciennes" dans le bassin de la Vézère, Bull. Soc. Préhist. Fr., 30, 543-559, 1933.

Plisson, H. and Geneste, J. M.: Analyse technologique des pointes à cran solutréennes du Placard (Charente), du Fourneau du Diable, du Pech de la Boissiere et de Combe-Saunière (Dordogne), Paléo, 1, 65-106, https://doi.org/10.3406/pal.1989.954, 1989.

Prüfer, K., Posth, C., Yu, H., Stoessel, A., Spyrou, M. A., Deviese, T., Mattonai, M., Ribechini, E., Higham, T., Velemínský, P., Brůžek, J., and Krause, J.: A genome sequence from a modern human skull over 45,000 years old from Zlatý kůň in Czechia, Nat. Ecol. \& Evol., 5, 820-825, https://doi.org/10.1038/s41559021-01443-x, 2021.

Schmidt, I., Hilpert, J., Kretschmer, I., Peters, R., Broich, M., Schiesberg, S., Vogels, O., Wendt, K. P., Zimmermann, A., and Maier, A.: Approaching prehistoric demography: proxies, scales and scope of the Cologne Protocol in European contexts, Philos. T. Roy. Soc. B. 376, 20190714, https://doi.org/10.1098/rstb.2019.0714, 2021. 